Furphy, Samuel. 'Philanthropy or Patronage?: Aboriginal Protectors in the Port Phillip District and Western Australia.' In Aboriginal Protection and Its Intermediaries in Britain's Antipodean Colonies, edited by Samuel Furphy and Amanda Nettelbeck, 58-76. New York and London: Routledge, 2020.

Please note: This is a pre-publication version made available according to the open access requirements of the Australian Research Council. Research for this chapter was conducted with the support of a Discovery Early Career Research Award (DE140100385, Samuel Furphy). Please consult the final published version here: https://doi.org/10.4324/9780429316364-4 


\title{
4
}

\section{Philanthropy or Patronage?}

\section{Aboriginal Protectors in the Port Phillip District and Western Australia ${ }^{1}$}

\author{
Samuel Furphy
}

When the British Colonial Office established Aboriginal protectorates in the Australian colonies in the late 1830s, most of the key personnel were appointed in London. This reflected the view expressed in the 1837 report of the Select Committee on Aborigines that 'the protection of the Aborigines should be considered a duty peculiarly belonging and appropriate to the executive government. ${ }^{2}$ The report envisaged the protectorates as a form of metropolitan philanthropic oversight of British settler populations and their treatment of Indigenous peoples. ${ }^{3}$ At least initially, such a policy was pursued by the Colonial Office and the evangelical philanthropists who controlled it, but this approach was short-lived, with primary responsibility for Aboriginal policy (including the appointment of officers) shifting quickly from London to the colonies, arguably by the early 1840 s, and certainly by the $1850 \mathrm{~s}$ when several Australian colonies were granted responsible government.

Indeed, a notable aspect of the Select Committee report was its fragile influence on colonial policy. Elizabeth Elbourne has described it as 'a contingent product of political circumstances that would not again align in the same manner.' 4 An important factor was the tenure of the evangelical Lord Glenelg (Charles Grant) as Secretary of State for War and Colonies (183539). The select committee chairman, Sir Thomas Fowell Buxton, counted both Glenelg and James Stephen (the permanent undersecretary at the Colonial Office from 1836) as key allies. ${ }^{5}$ Both were sons of members of the so-called 'Clapham Sect' of philanthropic reformers, which included both Buxton and William Wilberforce. And yet, if the appointments of Glenelg and Stephen to 
the Colonial Office were 'propitious for the humanitarian cause, ${ }^{7} 6$ then Glenelg's resignation in February 1839 was a marker of its limited reach and power. Moreover, Glenelg had been ably supported by his parliamentary undersecretary, Sir George Grey, ${ }^{7}$ who was an active evangelical and had supported Buxton as a member of the select committee; but Grey too resigned his position in the wake of Glenelg's departure. ${ }^{8}$

In this chapter, I explore how this shifting metropolitan political terrain shaped the early implementation of protective governance in the Australian colonies. I do so through a comparative analysis of the Aboriginal protectorates established in the Port Phillip District of New South Wales (from 1837) and in Western Australia (1839), focussing particularly on the appointment of the first protectors and the networks of patronage that shaped those appointments. In a period when protective governance was a contestable idea, and through its ambiguity one consistent with a variety of colonial practices, staffing decisions had the potential to profoundly shape the character of the new institutions. I argue that the resignation of Glenelg in early 1839 , before the Western Australian protectors had been appointed, helps to explain the diverging character of Aboriginal protection in the two colonies.

The difference between the two protectorates, put simply, was that the Port Phillip protectors were typically perceived as being opposed to settler interests, while in Western Australia settler interests were largely accommodated. The journalist and historian Thomas McCombie once described the Port Phillip protectors as "spys (sic) on the actions of the settlers ... [who] did not join cordially and in a generous spirit with the people to ameliorate the conditions of the aborigines ... [but] assumed an antagonistic position." ${ }^{\circ}$ Such criticisms were not echoed in Western Australia, where protests against protection policy more typically came from humanitarian critics, such as the lawyer, journalist, and radical William Nairne Clark, who in a letter to the Colonial Office in 1842 described the offices of protector as 'mere sinecures' that did nothing to protect Aboriginal interests. ${ }^{10}$ While the Port Phillip protectors were outsiders who often operated in tension with other colonial officials, in Western Australia they were more clearly integrated within an overarching scheme, where the civilising project was subordinated to the more practical aims of extending British jurisdiction and safeguarding settler economic interests. The protectorates also differed in the relative balance between their evangelical and secular roles: while the Port Phillip protectors emphasised the missionary character of their work, in Western Australia their civil and magisterial function was prioritised. ${ }^{11}$

How do we account for this contrast? The role of colonial governors was certainly important: John Hutt was proactive in setting Western Australia's distinctive policy; while in New South Wales, George Gipps was wary of the protectors appointed in the Port Phillip District and more concerned with establishing an alternative approach to protective governance elsewhere in 


\section{Philanthropy or Patronage?}

New South Wales. ${ }^{12}$ Money was also a factor: the salaries of the Port Phillip protectors were charged to the New South Wales colonial land fund, which amplified their unpopularity; while in Western Australia the positions were funded from London until 1854. ${ }^{13}$ In this chapter, however, I focus on the protectors themselves, especially the six appointed in London (four for Port Phillip, and two for Western Australia). While almost all were motivated by the salary on offer, the Port Phillip protectors (with only one exception) possessed a vocation for philanthropic (and especially evangelical) work, while the Western Australian protectors were colonial careerists with the right political connections. This contrast was itself the clear product of metropolitan patronage and political contingency. As the following analysis demonstrates, it mattered greatly who was appointed to the new positions of Protector of Aborigines, and biographical approaches help to reveal the complexity of protective governance.

\section{The Creation of the Port Phillip Protectorate}

The Port Phillip protectorate was the most significant result (in the Australian colonies at least) of the 1837 Select Committee report. An important influence during the committee proceedings had been the Lieutenant Governor of Van Diemen's Land, Sir George Arthur, who in letters both to Buxton and the Colonial Office elaborated a model of protective governance based on the supposed 'success' of George Augustus Robinson in conciliating Aboriginal people in Van Diemen's Land. ${ }^{14}$ Alan Lester and Fae Dussart have shown how Arthur 'both effected and was affected by shifts in humanitarian governmentality.' 15 While Superintendent of British Honduras (1814-22) he was committed to pursuing policies for the amelioration of slavey, which he then adapted to different ends in Van Diemen's Land. Having returned to London in 1837, he was on hand to advise the Colonial Office. Glenelg trusted Arthur and the two men were in regular contact. ${ }^{16}$ Arthur was thus able to profoundly shape the plans for protective governance in the expanding colonies of Australia, both in terms of policy prescription and the selection of protectors. ${ }^{17}$

Through Arthur's influence, Robinson was initially offered a position as protector in the new Colony of South Australia on $£ 250$ per annum, which he declined. Arthur then convinced Glenelg to appoint Robinson Chief Protector in the booming Port Phillip District at double the salary. ${ }^{18}$ According to Arthur's plan, Robinson was to be supported by four assistant protectors. These were all appointed in London, where Glenelg entrusted Arthur with the task of assessing candidates. Arthur requested sufficient time to fulfil this task, remarking that 'on a judicious selection of protectors the success of this benevolent undertaking entirely depends. ${ }^{, 19}$ One of the successful candidates later recalled that he had three interviews with Arthur and two with Sir George 
Grey prior to his appointment. ${ }^{20}$ This rigorous process of selection was not repeated when the Western Australian positions were filled in 1839.

To assemble a field of 11 candidates, Arthur consulted philanthropic, evangelical, military, and political networks. A key influence was his support for Methodists, whose work he had admired in Van Diemen's Land. ${ }^{21} \mathrm{He}$ had interacted positively with Rev. Joseph Orton, who facilitated a meeting in London between Arthur and Jabez Bunting, the influential secretary of the Wesleyan Methodist Missionary Society. ${ }^{22}$ Known as 'the Pope of Methodism,' Bunting was well connected within government networks and an associate of both Buxton and Stephen. ${ }^{23}$ Arthur asked Bunting to suggest four names for his consideration as assistant protectors. ${ }^{24}$ Two were eventually appointed: James Dredge (1796-1846), a school teacher and lay preacher from Salisbury, who had long aspired to missionary service; and Edward Stone Parker (1802-1865), a former candidate for the Methodist ministry and the master of a Methodist Day School in London. ${ }^{25}$ When Bunting wrote to Dredge on 18 November to describe the opportunity, he stressed that in addition to their civil or magisterial function the assistant protectors should have a missionary-like character, attending to 'the civilization, improvement, and salvation of the Natives.' In short, the Colonial Office was 'wishful that the Assistant Protectors should be decidedly religious men.'26

Dredge and Parker were certainly motivated by evangelical zeal, but it is apparent (and unsurprising) that they were also looking to their own prospects. There are hints in Dredge's journal and letters of financial problems in Salisbury: in 1839 he wrote that he had accepted the role 'to repair my drooping circumstances, ${ }^{27}$ while in 1840 he apologised to a friend in Salisbury for 'not having done anything to discharge the obligations I am under to you.'28 Dredge's letters also reveal his expectation of preaching work in Port Phillip if his role as an assistant protector proved untenable, in which hope he had the discreet support of Bunting. ${ }^{29}$ Parker was also beset by financial challenges. In May 1837, the committee of his school met to discuss his 'unsettled state of affairs, his large and increasing family, \&c \&c.,' and a month later it offered Parker's creditors two shillings and sixpence in a pound to resolve a debt of approximately $£ 400$. The school itself was also in financial difficulty due to poor enrolments, and in November, the committee decided to relieve Parker's wife of her position as mistress of the Girls School. For Parker, the opportunity to take the role of assistant protector was ideally timed, not least for its salary of $£ 250$, which dwarfed his teacher salary of $£ 75$. When resigning, he thanked the committee for its support 'in circumstances of complicated affliction and difficulty., 30

Another of George Arthur's recommended candidates, William Thomas (1793-1867), was also a school teacher of Wesleyan faith, but he was not among the candidates recommended by Bunting. Rather, it was his links to political and philanthropic networks that secured his appointment. Thomas had for 21 years owned a successful school in Old Kent Road, and more 
recently had tutored 'scions of the nobility' who aspired to careers in the civil service; he thus became known in official circles as 'a person of good sense, tact, and integrity.' ${ }^{31}$ He was recommended to Arthur by two women: the Dowager Lady Ilchester (Maria Fox-Strangways, née Digby), whose son William Fox-Strangways was Under-Secretary of State for Foreign Affairs; and Amelia Murray, an advocate of juvenile reformatories and maid of honour to Queen Victoria. ${ }^{32}$ Thomas later recalled in a letter to Charles La Trobe, the superintendent of the Port Phillip District, that he regularly attended sessions of the parliament in Westminster: 'It was on one of these occasions I was brought into notice \& asked by Lady M (who was intimately acquainted with Ld Glenelg \& one of the Ladies in Waiting) "if I should not like to go abroad $\&$ protect the poor blacks." His motivation to abandon his successful school and migrate appears to have been religious rather than economic, as he explained to La Trobe: "The Missionary chronicle \& other accounts of the heathens had long affected me, [and] after consulting some religious friends I accepted Lady M's recommendation \& in a few days my appointment. ${ }^{, 33}$

The fourth applicant that George Arthur recommended was Charles Sievwright (1800-1855), who differed markedly from his future colleagues with their Wesleyan faith and evangelical motivations. Sievwright was a morally complex former officer in the Royal Fusiliers, who had sold his commission to pay off gambling debts accumulated during an unremarkable military career. ${ }^{34}$ In his report to Glenelg, Arthur strongly endorsed Sievwright, suggesting he would be suitable as Chief Protector if Robinson did not accept the position. ${ }^{35}$ This was certainly a misjudgement; before Sievwright had left London the Colonial Office was alerted to his apparent neglect of financial and family responsibilities. ${ }^{36}$ But Sievwright had several influential patrons, including Lord Frederic Fitzclarence, a former commanding officer of the Fusiliers and illegitimate son of King William IV; Fitzclarence's brother-in-law Lord Falkland, who was chief government whip in the House of Lords; and Viscount Duncannon, the Lord Privy Seal. ${ }^{37}$

\section{Missionaries or Magistrates?}

With the exception of Sievwright, the assistant protectors were more or less connected to the evangelical and philanthropic networks led by Buxton; as Lisa Ford has put it, they were 'clients of the same movement., ${ }^{38}$ These links were something of a liability when the protectors arrived in Sydney (en route to Melbourne), where they encountered the antipathy of many settlers towards their appointments. Thomas, who was the first to arrive in August 1838, wrote home that he was 'assailed on all sides' and that 'all the scurrilous language that could be made use of was employed in defaming My Lord Glenelg and the new created Office of Protectors, the poor Aborigines were designated as Brutes, Beasts and denied almost the lineage of humanity. 39 


\section{Philanthropy or Patronage?}

The protectors were not completely isolated. On 29 September, Dredge, Thomas, Parker, and Robinson all attended a meeting at which an Australian branch of the Aborigines Protection Society was formed. ${ }^{40}$ But they witnessed strong opposition to the trial of white men for the massacre of Aboriginal people at Myall Creek. Dredge attended the Supreme Court on the day a not guilty verdict was returned in the first Myall Creek trial and wrote in his diary: 'Never was a case of murder more clearly proved by a clear connected chain of evidence and never in a court of English judicature was there a grosser dereliction of duty in the Jury box! ${ }^{41}$ Rebecca Wood has shown that the Myall Creek trials and the appointment of protectors were 'two interconnected events which triggered heated debate in the colony. ${ }^{, 42}$ The Sydney Herald was the most extreme in its criticisms, describing the protectors as 'useless officials' and accusing them of laziness and 'indulging in all of the luxuries of life, in idleness, meetings, speechifying, and many other useless matters.' The newspaper also criticised their status as family men, insisting that the protectors should be 'unmarried men able to contend against the privations of a bush life. ${ }^{43}$

Despite its prejudiced and libellous tone, the Sydney Herald may have had a valid point to make about the protectors' family responsibilities. A year earlier Arthur had emphasised to Glenelg that all four of his recommended candidates were married men. He clearly saw this as an advantage, suggesting that 'their wives may be made highly useful ... [for] some trifling remuneration'; he also drew attention to Thomas and Dredge's sons. ${ }^{44}$ Arthur's emphasis on family may have made sense if the protectors' evangelical function was prioritised; but the requirement that protectors itinerate with Aboriginal peoples did not suit their familial commitments or missionary aspirations. Robinson, too, was concerned by this, complaining in April 1839 that Thomas and Dredge were "not the men for the work, always talking of wives and families and of rations. ${ }^{, 45}$

This tension around the role of family reflected a broader ambiguity in the protectors' job description-were they to be magistrates or missionaries? Arthur and Glenelg clearly thought these roles were complementary, but the Governor in Sydney, George Gipps, was not convinced. In a despatch in 1841 to Lord John Russell (a successor to Glenelg at the Colonial Office) he complained that 'they are all encumbered . . . with large families, and seem to have come to Australia with the expectation of establishing missionary stations, rather than of itinerating with and amongst the tribes.' Gipps had sanctioned the 'formation of a homestead or fixed station for each assistant protector,' which to some extent had the character of a mission station; but he insisted that, confined to these locations, the protectors could have 'no influence whatever in checking the atrocities which are committed whenever land is occupied for the first time.' This task required, Gipps argued, 'young men, unencumbered with families ... and accordingly I have universally selected such to be our commissioners of Crown lands. ${ }^{46}$ This comparison 


\section{Philanthropy or Patronage?}

with the commissioners is significant: in all parts of New South Wales except the Port Phillip District, Gipps had entrusted the commissioners with the role of protecting Aboriginal people, just as they extended the government's protection to settlers. Only in Port Phillip was the specific role of protecting Aboriginal people allocated to dedicated officers. Gipps clearly thought his approach was more appropriate. ${ }^{47}$ By 1842 he was content to dismiss the value of the whole protectorate department: 'it would be difficult, I think, to find men less equal to the arduous duty of acting as protectors of the aborigines, than those who were selected for this purpose in England in 1838. ${ }^{48}$

In his despatches to London, Gipps asserted the protectors' apparent unsuitability for their assigned task; but in his local correspondence with $\mathrm{La}$ Trobe, his suspicion of their philanthropic purpose was evident. This is particularly true in relation to the Lettsom Raid in October 1840, when the protectorate's marginal status was exposed. On 29 August 1840 Gipps wrote to La Trobe explaining that he had sent Major Lettsom on a 'secret' mission to inquire into and report on 'great atrocities' being committed by Aboriginal people at the Ovens River, 250 kilometres north east of Melbourne. He noted that he did not have 'full confidence in the ability and activity' of the Chief Protector, but instructed La Trobe to 'exercise you own discretion in sending Mr. Robinson, or anybody else. ${ }^{49}$ In a despatch to the Colonial Office, Gipps later insisted that the attacks on livestock were 'a preconcerted measure of revenge or retaliation. ${ }^{50}$ In this context, he had authorised Lettsom to 'detain as hostages for the good conduct of any tribe a reasonable number of Individuals belonging to it if the actual Perpetrators of any outrage cannot be apprehended. ${ }^{51}$ Finding no Aboriginal people at the Ovens River, Lettsom proceeded to Melbourne where the various Kulin nations had gathered for inter-tribal ceremonies. William Thomas refused Lettsom's request to hand over hostages from each of the tribes. Then, on 11 October, Lettsom and his soldiers violently rounded up more than $300 \mathrm{Kulin}$ people, who were 'goaded with bayonets' as they were driven to the stockade. ${ }^{52}$ Edward Parker managed to secure the release from prison of most of those captured, but 35 were held until mid-November, when ten were charged and tried. ${ }^{53}$

If Gipps was not confident that Chief Protector Robinson could provide Lettsom with the support he deemed necessary, neither did Thomas or Dredge trust Robinson to represent the interests of Kulin people. In a letter to Bunting, Dredge observed that Robinson was present at a meeting when the capture was planned but 'took no steps towards the protection of the poor Creatures'; the whole affair was, he said, 'alike disgraceful to the British name and cruel to the defenceless blacks. ${ }^{54}$ Gipps later admitted to Russell that Lettsom had 'departed in some degree from the instructions which I had given to him' but insisted that he had not exceeded appropriate 'discretionary powers'; he also reported Lettsom's complaint that Thomas had obstructed him in his duty. ${ }^{55}$ In a letter to Robinson, Thomas had described Lettsom's request for hostages as tantamount to martial law; he justified his obstruction with reference to his 


\section{Philanthropy or Patronage?}

'instructions from the Home Government' and his determination to act 'as a protector to the liberties of the aborigines.' 56 Gipps subsequently read Thomas's letter and forwarded it to London; it seems likely that Thomas's reference to his 'instructions from the Home Government' prompted Gipps to warn La Trobe on 24 October that 'the utmost circumspection will be necessary in respect to the Protectors.' A few weeks later he added that 'persons perhaps more powerful than the Government' would believe and act on the protectors' reports. ${ }^{57}$

Two of the assistant protectors at Port Phillip had relatively short careers. Dredge resigned in mid-1840 and became a strong critic of the protectorate's secular focus. In a letter to Bunting he described it as a 'godless political experiment' and criticised Gipps's lack of support. ${ }^{58} \mathrm{He}$ later published a pamphlet decrying 'the utter inefficiency, useless expenditure and mischievous tendency of the [protectorate] system.' ${ }^{59}$ Meanwhile, Sievwright attempted (assiduously but unsuccessfully) to prosecute settler violence against Aboriginal people in his district to the west of Melbourne. ${ }^{60} \mathrm{He}$ became extremely unpopular-one pastoralist described him as 'the most unpopular man that ever breathed' ${ }^{\prime \prime}$ _ and was eventually dismissed in 1842 amidst accusations of incest and adultery. ${ }^{62}$ He became a focus of the settler backlash against the protectorate, although Robinson too was criticised. Thomas and Parker persevered and achieved modest outcomes in the context of what became a doomed department. In 1843 Gipps significantly reduced the protectorate's budget and Thomas was ordered to abandon the station he had formed at Nerre Nerre Warren, near Melbourne. Thomas blamed the lack of Kulin people residing at his station on the government's firm policy that rations would only be provided in exchange for Aboriginal labour. ${ }^{63}$ Ian Crawford has observed that after 1843 Thomas 'became tactful in his approach to his superiors, more judicious in his statements, and much more conservative.' ${ }^{64}$ But when the protectorate was closed in 1849, he again emphasised to La Trobe that he had been appointed by the Home Government 'for life.' ${ }^{65} \mathrm{La}$ Trobe made him 'Guardian of Aborigines,' in which position he served until the 1860 s.

The influence of Glenelg, Arthur, Bunting, and Grey on the appointment of assistant protectors for Port Phillip largely explains the missionary character of the protectorate; it also helps explain its unpopularity with settlers, and the tension between its officers and the colonial administrators to whom they reported. But a clash between protective governance and settler interests was not inevitable. In Western Australia, a system evolved that largely accorded with settler expectations; the reasons for this can be at least partly attributed to the process by which the protectors were appointed.

\section{Protectors for Western Australia}




\section{Philanthropy or Patronage?}

In the months following the release of the Select Committee report in 1837, Western Australia was not an immediate priority among officials at the Colonial Office. And yet, when George Arthur described his vision for Aboriginal protection to Glenelg in July, he had suggested the appointment of a team of assistant protectors under the direction of Robinson, whose responsibility would extend 'even so far as Gulf St Vincent' (South Australia) and that 'the scheme might still further be extended so as to include King George Sound and Swan River' (Western Australia). ${ }^{66}$ In a letter to Treasury in August, Glenelg appeared to adopt Arthur's idea of a trans-colonial scheme, proposing that Robinson would oversee the work of four assistant protectors, one of whom was to be stationed in South Australia. ${ }^{67}$ Although this never eventuated, it indicates the extent to which Arthur and Glenelg imagined the protectorate as a semi-independent agency, operating separately from (or at least parallel to) the governor of each colony. As it happened, however, the protector in Adelaide reported directly to the South Australian governor; three interim protectors served there until the permanent appointment of Matthew Moorhouse in 1839.

For the time being, the Western Australian settlements were overlooked. Then, in July 1838, Louis Giustiniani, an Italian-born Anglican missionary who had returned to London from Western Australia, drew the Colonial Office's attention to what he called 'a system of cruelty oppression and injustice. ${ }^{68} \mathrm{He}$ described a series of violent or unjust encounters between settlers and Aboriginal people and offered his services as a protector. Giustiniani had earlier written a series of open letters to Glenelg for the Swan River Guardian, published by William Nairne Clark. ${ }^{69}$ The first of these had described an incident on the property of the government resident at the inland town of York, R.H. Bland, during which an Aboriginal man was shot while stealing flour from a barn. Giustiniani claimed a man had been 'stationed there to inflict this summary punishment . . . [and] to shoot the Native in cold blood' when there was 'equal power to prevent as well as punish the crime. ${ }^{70}$ Although Bland himself was not present, his association with Giustiniani's campaign is significant, as he would later be appointed Protector of Aborigines at York.

Missionary critiques of settler violence had, of course, been a critical component of the select committee inquiry, and the Colonial Office treated Giustiniani's reports seriously. His offer to serve as protector was overlooked due to an unfavourable reference from the Church Missionary Society, ${ }^{71}$ but Glenelg instructed Governor John Hutt, who was soon to depart for Western Australia, to investigate the claims. He also convinced the British Treasury to fund two protectors for Western Australia. ${ }^{72}$ Significantly, however, these were among Glenelg's last acts in his portfolio, as he was forced to resign from Cabinet in February 1839.

Glenelg's tenure at the Colonial Office had for some time been under a cloud. His intervention in the Cape Colony in 1835 , when he refused to 
countenance Sir Benjamin D'Urban's annexation of the Queen Adelaide Province, surprised contemporaries who 'found his concern for the rights of indigenous people incomprehensible, and interpreted a principled stand as obstinate irresolution. ${ }^{73}$ Many of his colleagues were concerned about his handling of the Upper Canada rebellion and about an impending clash with Jamaican planters. Lord Melbourne's government was under constant pressure from Radicals in the parliament and the removal of Glenelg seemed the best means of assuaging their concerns and resolving the instability. ${ }^{74}$ As Edith Dobie has observed: 'Glenelg's insistence upon acting on principle must have been most annoying to a cabinet living almost from day to day and, therefore, frequently guided by expediency. ${ }^{, 75}$

Wearied by the attacks of his opponents in the parliament, Glenelg allowed a shallow and seemingly false perception of him as lazy and incompetent to take hold. James Stephen observed 'the strange incompatibility of his temper and principles with the rules of action to which we erect shrines in Downing Street. ${ }^{76}$ Buxton thought him much maligned and that no Colonial Secretary had acted with 'more justice and conscience. ${ }^{77}$ Lord John Russell, the Home Secretary, had earlier offered to swap portfolios with Glenelg, but he did not immediately take control at the Colonial Office after Glenelg resigned. Rather, a new addition to the Cabinet, Lord Normanby (Constantine Henry Phipps), held the portfolio for a few months in the first half of 1839 . He had recently returned to parliament after appointments as Governor of Jamaica and as Lord Lieutenant of Ireland (1835-39). The task of appointing the new Western Australian protectors thus fell to Normanby, and the contrast between the Western Australian protectors and their contemporaries in Port Phillip was considerable.

The first protector appointed was Charles Symmons (1804-1887), whose wealthy father John Symmons was a patron of scientific and literary endeavour in London. Symmons senior had resided in a Georgian mansion on Paddington Green, where he assembled a famous horticultural collection and a valuable library, while devoting his time to various learned societies. ${ }^{78}$ Charles was born in 1804, five months after his father's third marriage. He presumably benefited from his father's wealth and was probably educated privately. His mother died in 1813. Charles married Joanne Elliott in November 1825 , five months before the birth of their first child. There is evidence of estrangement from his father over the following years: when John Symmons married for the fourth time in 1828 , he wrote a will that excluded Charles, but not Charles's younger brother. ${ }^{79}$ John later reversed this decision in a codicil, but it mattered little as he had meanwhile suffered a 'reversal of fortune,' whereupon he fled to Belgium to escape his debts, dying there in 1831. Charles was subsequently involved in at least one court case associated with his father's estate. ${ }^{80}$ In 1836 he wrote meekly to the Literary Fund Society (of which his father had been a vice president) explaining that he was 'reduced to such a state of utter destitution, as to be compelled to throw himself on the 


\section{Philanthropy or Patronage?}

liberality of the [society] ... for relief. ${ }^{81}$ His request was declined and it is unclear how he supported his family, but in 1839 he secured the patronage of George Villiers, the Earl of Clarendon. The connection between the men is not entirely clear, but Clarendon's father had been, with John Symmons, a founding member of the Royal Institution in 1799. ${ }^{82}$

Clarendon had returned to London in 1839 after a period as Minister Plenipotentiary to Spain, and he would soon join Lord Melbourne's cabinet. He apparently had some influence on Normanby: they were of a similar age, they had both recently returned from diplomatic postings, and they possibly knew each other as contemporaries in neighbouring colleges at Cambridge. ${ }^{83}$ On 9 May 1839 Clarendon wrote a short private note to Normanby, requesting that he find for Symmons, a 'small place in the Colonies, such as a gentleman may fill. ${ }^{84}$ Normanby obliged, and Symmons commenced duty as a protector in Perth the following January. There is no evidence that any consideration was given to his suitability for the role. He was apparently neither evangelical, nor otherwise exercised by the humanitarian concerns of the period. He had no previous experience in government service.

Patronage was similarly important in the appointment of a second protector for Western Australia, Peter Barrow (1813-99), who was stationed inland at York. Barrow was the youngest of six children of Sir John Barrow, the Second Lord of the Admiralty (1804-45). ${ }^{85}$ Sir John had often used his influence in military networks to secure an appointment for his wayward son. In 1831 he arranged for Peter to enrol at the East India College, through his friendship with one of the directors. ${ }^{86}$ Withdrawing from the college in 1833, Peter then undertook theological training but was never ordained. He then travelled to Sierra Leone in 1836, where he served in various administrative roles before ill health forced him home in April 1837. ${ }^{87}$ His appointments in Sierra Leone likely resulted from the friendship between the colony's Lieutenant Governor, Henry Dundas Campbell, and his elder brother John. ${ }^{88}$ Peter's next venture was to Van Diemen's Land. The new governor in Hobart, Sir John Franklin, had a close association with Sir John Barrow, who had fostered his earlier career as an arctic explorer. A Hobart journalist later opined that Peter Barrow 'was sent out here by his father to his old friend Sir John Franklin, to give him a comfortable situation under his Government. ${ }^{, 89} \mathrm{He}$ was employed as a catechist at the establishment for juvenile convicts at Point Puer, ${ }^{90}$ but left Hobart in February 1839 after a disagreement with Franklin had culminated in a public brawl between Barrow and one of Franklin's clerks. ${ }^{11}$

When Barrow returned to Britain, his father immediately intervened to secure another appointment for his son. On 6 June he wrote to Henry Labouchere, who had replaced Sir George Grey as parliamentary undersecretary at the Colonial Office. As a former Civil Lord of the Admiralty, Labouchere would have known Sir John Barrow well. Barrow opened his letter with an apology: 'I fear you will think me troublesome but when anxiety for the welfare of a son is in the case I am sure I shall have your excuse.' He 
suggested that a position as Protector of Aborigines in Western Australia would be 'entirely congenial with the feelings and disposition of my Son.' He asked Labouchere to communicate his wishes to Lord Normanby, who he thought might be amenable due to Sir John's association with Lord Normanby's father, the first Earl of Mulgrave, a former First Lord of the Admiralty (1807-10). ${ }^{92}$

Sir John Barrow's lobbying was successful and Peter Barrow was appointed, but he proved an ineffectual and easily disillusioned protector, who lacked confidence in his role, especially without the closer guidance from Governor Hutt that Symmons enjoyed in Perth. ${ }^{93}$ Barrow seemed more interested in establishing a school for non-Indigenous children, hoping to lure students whose parents were resident in India. ${ }^{94} \mathrm{He}$ soon lost the confidence of the Governor, who criticised him for not adequately investigating incidents of violence. In July 1841 Barrow complained that the Governor 'had once more formed a hasty opinion of my conduct,' but he resigned on 30 September. ${ }^{95}$ He was replaced by R.H. Bland, the resident magistrate at York and a pioneer settler. Following his return to Britain, Barrow found his way to Caen in France, where he married a local woman. In 1845 his father intervened once again to get him appointed a Vice-Consul. When he requested a promotion in 1856, a Foreign Office clerk noted that Barrow was 'believed formerly to have given his father some trouble. ${ }^{, 96}$

\section{Western Australia's 'System of Native Management'}

Meanwhile, in Perth, Charles Symmons faithfully implemented John Hutt's vision for protective governance, which prioritised policing and the systematic punishment of Aboriginal crimes against settler property. Hutt believed this would bring Aboriginal people within British jurisdiction and thereby prevent settlers from 'taking the law into their own hands. ${ }^{97}$ As Amanda Nettelbeck has shown, he also saw conciliation to British authority as an essential prerequisite for any schemes for the civilisation of Aboriginal people. ${ }^{98}$ Symmons quickly became an eloquent and enthusiastic advocate for what he often called, in his reports to Hutt, the 'system of native management.' In his second quarterly report he noted the apprehension of 'several notorious Native offenders,' which would serve as an example that 'no period of time will screen the guilty from that punishment which will sooner or later overtake him. ${ }^{99}$ A year later he praised the notorious Rottnest Island prison, describing its 'undefined terrors' as a strong deterrent to Aboriginal crime. ${ }^{100}$ In his annual report for 1842 he insisted that peaceful relations between settlers and Aboriginal people were the result of the enforcement of police regulations and 'our physical \& mental superiority so universally acknowledged.' In a phrase that captured Western Australia's unique iteration of protective governance, Symmons insisted 'that a halo of protection now encircles the life of the white 
man - that property is with rare exceptions safe from aggression-that an armed or naked savage is never seen.' ${ }^{, 101}$

From York, the new protector R.H. Bland similarly attributed a lack of Aboriginal aggression to 'the fear of detection, and the certainty of punishment. ${ }^{102}$ Both protectors advocated extensive police resources throughout the $1840 \mathrm{~s}$, also asserting the need to extend the powers of magistrates to summarily convict Aboriginal offenders. ${ }^{103}$ In 1848 Symmons expounded the logic of the Western Australian approach, writing 'that the Protectors are most effectually advancing the best interests of their sable clients, by identifying themselves equally with those of the settlers, by protecting them from the aggressions of the aborigines, and thereby ... promoting a mutual reciprocity of good feeling. ${ }^{104}$ The following year Governor Charles Fitzgerald obligingly changed Symmons' job title to Guardian of Aborigines and Protector of Settlers (emphasis added). In his 1942 study of Western Australian race relations, Paul Hasluck summed up the position of protector: "their role became not solely that of "mediator" or defender of native interests but largely that of a policeman to ensure the safety of white lives and property. ${ }^{105}$ Symmons remained in the role until 1856, before becoming Commissioner of Police, a natural enough progression in the circumstances.

\section{Conclusion}

This chapter has examined the different patterns of patronage that led to the appointment of protectors of Aborigines for the Port Phillip District of New South Wales (1837) and for Western Australia (1839), which help to explain the varied histories of protective governance in each colony. The idea of Aboriginal protection was complex and, in many respects, contradictory, combining amelioration, Christianisation, and legal protection, with conciliation, pacification, and control. Aboriginal protectors were thus often in the ambiguous position of being both 'advocates for Aboriginal peoples' and 'agents of the colonial state.' ${ }^{106}$ This ambiguity fostered a variety of responses to the question of how best to 'protect' Aboriginal people. Both Amanda Nettelbeck and Ann Hunter have emphasised the important role of John Hutt in shaping the policy approach in Western Australia, while Lisa Ford has explored Gipps's influence in New South Wales. ${ }^{107}$ While not disputing the important role of governors, I have argued that the personalities and proclivities of the protectors themselves were highly significant, and that these were themselves a product of changing patterns of patronage at the Colonial Office in London.

Created shortly after the Select Committee on Aborigines, the Port Phillip protectorate was the purest expression of the evangelical, antislavery, and philanthropic ideals that had inspired both Buxton's report and Glenelg's colonial policy. This strong link between philanthropic networks and the 


\section{Philanthropy or Patronage?}

Colonial Office was weakened, however, by the resignation of Glenelg and Grey in early 1839, allowing the appointment of protectors for Western Australia who did not evince the same qualities as their colleagues in Port Phillip. We might compare, for example, how faithfully Symmons implemented Governor Hutt's settler-focussed policy, to the indignant protests of Thomas and Dredge in Port Phillip when Governor Gipps bypassed the protectorate during the Lettsom Raid. With George Arthur's help, Glenelg was able to staff the Port Phillip protectorate with metropolitan philanthropists who embodied the form of external oversight that the Select Committee report had envisioned. In contrast, the Western Australian protectors were not humanitarian idealists, but men in search of a colonial sinecure. Charles Symmons, in particular, was just the man to implement the policy of a governor whose vision for protective governance diverged considerably from the version promulgated by evangelical philanthropists in the Select Committee report.

\section{Notes}

${ }^{1}$ Research for this chapter was conducted with the support of an Australian Research Council grant, DE140100385.

${ }^{2}$ House of Commons Parliamentary Papers 1837 (425), Report from the Select Committee on Aborigines (British Settlements), 77.

${ }^{3}$ Elizabeth Elbourne, 'The Sins of the Settler: The 1835-36 Select Committee on Aborigines and Debates over Virtue and Conquest in the Early NineteenthCentury British White Settler Empire', Journal of Colonialism and Colonial History 4. 3 (2003).

${ }^{4}$ Elbourne, 'The Sins of the Settler', 8.

Alan Lester and Fae Dussart, Colonization and the Origins of Humanitarian Governance: Protecting Aborigines across the Nineteenth-Century British Empire (Cambridge: Cambridge University Press, 2014), 86.

${ }^{6}$ Ronald Rainger, 'Philanthropy and Science in the 1830's: The British and Foreign Aborigines' Protection Society', Man 15. 4 (1980), 706.

${ }^{7}$ Sir George Grey, the British MP referred to here, should not be confused with (Sir) George Grey, the colonial governor who is profiled by Richard Price in chapter 2 of this volume.

${ }^{8}$ David Frederick Smith, 'Grey, Sir George, Second Baronet (1799-1882)', Oxford Dictionary of National Biography (Oxford: Oxford University Press, 2004), www.oxforddnb.com/view/article/11533; James Heartfield, The Aborigines' Protection Society: Humanitarian Imperialism in Australia, New Zealand, Fiji, Canada, South Africa, and the Congo, 1837-1909 (New York: Columbia University Press, 2011), 15.

9 Thomas McCombie, The History of the Colony of Victoria: From Its Settlement to the Death of Sir Charles Hotham (Melbourne: Sands and Kenny, 1858), 96. 
10 William Nairne Clark to Lord Stanley, 7 March 1842, HCPP 627, 414; see also Amanda Nettelbeck, "A Halo of Protection": Colonial Protectors and the Principle of Aboriginal Protection through Punishment', Australian Historical Studies 43.3 (2012), 408.

For a more detailed discussion of the differences between the Port Phillip protectorate and other contemporaneous Australasian protectorates, see Amanda Nettelbeck's chapter in this volume.

For Hutt's influence, see Nettelbeck, “"A Halo of Protection"'; see also Ann Hunter, 'Towards Amalgamationist Governance: Governor Hutt and Contradictions in British Colonial Policy Regarding Aboriginal People in Western Australia', Law \& History 5. 1 (2018), 85; for Gipps's alternative plan, see Lisa Ford, 'Protecting the Peace on the Edges of Empire: Commissioners of Crown Lands in New South Wales', in Lauren Benton, Adam Clulow and Bain Attwood, eds., Protection and Empire: A Global History (Cambridge: Cambridge University Press, 2017), 17593.

${ }^{3}$ Michael Cannon, ed., The Aborigines of Port Phillip, 1835-1839, vol. 2A: Historical Records of Victoria, Foundation Series (Melbourne: Victorian Government Printing Office, 1983), 28-9; Paul Hasluck, Black Australians: A Survey of Native Policy in Western Australia, 1829-1897 (Melbourne: Melbourne University Press, 1942), 80.

Cannon, The Aborigines of Port Phillip, 1835-1839, 2A:5-8, 12-16.

Lester and Dussart, Colonization and the Origins of Humanitarian Governance, 37.

A. G. L. Shaw, Sir George Arthur, Bart., 1784-1854 (Melbourne: Melbourne University Press, 1980), 171, 177; Cannon, The Aborigines of Port Phillip, 18351839, 2A:27.

Lester and Dussart, Colonization and the Origins of Humanitarian Governance, 104-6.

${ }^{8}$ Cannon, The Aborigines of Port Phillip, 1835-1839, 2A:21-4.

Cannon, The Aborigines of Port Phillip, 1835-1839, 2A:31.

William Thomas to Charles La Trobe, 19 September 1849, reproduced in Marguerita Stephens, ed., The Journal of William Thomas: Assistant Protector of the Aborigines of Port Phillip \& Guardian of the Aborigines of Victoria 1839 to 1867 (Melbourne: Victorian Aboriginal Corporation for Languages, 2014), 407.

Shaw, Sir George Arthur, Bart., 1784-1854, 145.

Alex Tyrrell, A Sphere of Benevolence: The Life of Joseph Orton, Wesleyan Methodist Missionary (1795-1842) (Melbourne: State Library of Victoria, 1993), 141.

T. M. O'Connor, Protector Edward Stone Parker, Port Phillip Gentleman: UCA Historical Society (Victoria) Synod Lecture 1991 (Melbourne: Uniting Church Historical Society (Victoria), 1991), 5-6; see also Patricia M. Pugh, ed., Calendar of the Papers of Sir Thomas Fowell Buxton, 1786-1845 (London: Swift Printers, 1980).

${ }^{24}$ John Radford to Mary Tooth, 26 February 1838, Fletcher-Tooth Collection, GB 135 MAM/FL/6/2/22, John Rylands Library, University of Manchester, https://archiveshub.jisc.ac.uk/manchesteruniversity/data/gb133$\mathrm{mam} / \mathrm{fl} / \mathrm{mam} / \mathrm{fl} / 6 / 2 / 22$ (accessed 4 May 2018).

See Colin A. McCallum, 'James Dredge, 1796-1846', Heritage: A Journal of the Methodist Historical Society of Victoria 8 (1957), 1-23; for some recent work on Parker, see Bain Attwood, The Good Country: The Djadja Wurrung, the Settlers and the Protectors (Clayton: Monash University Publishing, 2017). 
Jabez Bunting to James Dredge, 18 November 1837, Methodist Archives and Research Centre, PLP 19/4/19, John Rylands Library, University of Manchester.

James Dredge journal, 28 April 1839, cited in Ian D. Clark, Goulburn River Aboriginal Protectorate: A History of the Goulburn River Aboriginal Protectorate Station at Murchison, Victoria, 1840-1853 (Ballarat: Ballarat Heritage Services, 2013), 21.

James Dredge to W. Harding, 3 July 1840, James Dredge Letterbook (1839-1845), MS 11625, Box 16/6, State Library of Victoria.

James Dredge to Rev James Watkin, 3 October 1839, James Dredge Letterbook (1839-1845), MS 11625, Box 16/6, State Library of Victoria.

0 Great Queen Street Chapel, Lincoln's Inn Fields, 2nd London Circuit Day School Committee minutes (1836-70), 19 May, 23 June, 28 October, 10 November, 22 December 1837. London Metropolitan Archives, N/M/007/021.

1 'Mr William Thomas, the Aboriginal Guardian', Leader (Melbourne), 30 May 1863, 1, <http://nla.gov.au/nla.news-article197290340> (accessed 14 April 2018).

K. D. Reynolds, 'Murray, Amelia Matilda (1795-1884)', Oxford Dictionary of National Biography (Oxford: Oxford University Press, 2004), www.oxforddnb.com/view/article/19589.

William Thomas to Charles La Trobe, 21 September 1849, VPRS 10, item 1849/1845, Public Record Office of Victoria.

${ }^{34}$ Lindsey Arkley, The Hated Protector: The Story of Charles Wightman Sievwright, Protector of Aborigines, 1839-42 (Mentone: Orbit Press, 2000), 55.

${ }^{35}$ Cannon, The Aborigines of Port Phillip, 1835-1839, 2A:33.

36 Michael Cannon, ed., Aborigines and Protectors, 1838-1839, vol. 2B, Historical Records of Victoria, Foundation Series (Melbourne: Victorian Government Printing Office, 1983), 368-73.

Cannon, The Aborigines of Port Phillip, 1835-1839, 2A:33; see also Arkley, The Hated Protector, 56-7.

Ford, 'Protecting the Peace on the Edges of Empire', 188.

William Thomas, draft letter to unknown recipient, November 1838. William Thomas papers, Volume 1: journals, 1839-1844 and associated papers, 18341838; MLMSS 214/1. Microfilm: CY 2604, frames 269-270.

Australian Aborigines' Protection Society, The Australian Aborigines' Protection Society: Instituted 1838 (Sydney: James Spilsbury, 1838).

${ }^{41}$ James Dredge, Diary, 15 November 1838, MS 5244, State Library of Victoria.

Rebecca Wood, 'Frontier Violence and the Bush Legend: The Sydney Herald's Response to the Myall Creek Massacre Trials and the Creation of Colonial Identity', History Australia 6. 3 (2009), 67.4.

Sydney Herald, November 1838, quoted in Wood, 67.9.

Cannon, The Aborigines of Port Phillip, 1835-1839, 2A:31, 34, 36.

Ian D. Clark, The Journals of George Augustus Robinson, Chief Protector, Port Phillip Aboriginal Protectorate, vol. 1 (Ballarat: Heritage Matters, 2000), 27.

${ }^{46}$ Gipps to Lord John Russell, 3 February 1841, HCPP 627, 87.

For a more detailed analysis, see Ford, 'Protecting the Peace on the Edges of Empire'.

${ }^{48}$ George Gipps to Lord Stanley, 16 May 1842, in Despatches of the Governors of the Australian Colonies, with the Reports of the Protectors of Aborigines. House of Commons Parliamentary Papers (HCPP), no. 627 (1844), 216.

49 Gipps to La Trobe, 29 August 1840, in A. G. L. Shaw, Gipps-La Trobe Correspondence 1839-46 (Carlton: Melbourne University Press, 1989), 45-6.

50 Gipps to Lord John Russell, 3 February 1841, HCPP 627, 86. 
Colonial Secretary to Major Lettsom, 28 August 1840, HCPP 627, 92; see also Rachel Standfield, 'Protection, Settler Politics and Indigenous Politics in the Work of William Thomas', Journal of Colonialism and Colonial History 13. 1 (2012).

52 George Robinson, 11 October 1840, relating the evidence of a witness, $\mathrm{Mr}$ Wilkinson, in Clark, The Journals of George Augustus Robinson, vol. 2, 7-10.

For an account of the raid, see Lester and Dussart, Colonization and the Origins of Humanitarian Governance, 129-33.

44 Dredge to Bunting, 10 May 1841, James Dredge Letterbook (1839-1845), MS 11625, Box 16/6, State Library of Victoria.

Sir George Gipps to Lord John Russell, 3 February 1841, HCPP 627, 86-87.

Thomas to Robinson, 29 September 1840, HCPP 627, 95-6.

Gipps to La Trobe, 24 October and 12 December 1840, in Shaw, Gipps-La Trobe Correspondence 1839-46, 48-9, 51-3.

James Dredge to Jabez Bunting, 31 July 1840, Letterbook, April 1839-January 1845, MS 11625, Box 16/6, State Library of Victoria.

James Dredge, Brief Notices of the Aborigines of New South Wales Including Port Phillip in Reference to Their Past History and Present Conditions (Geelong: James Harrison, 1845), 3.

60 Lester and Dussart, Colonization and the Origins of Humanitarian Governance, 137-8.

1 Arkley, The Hated Protector, 60.

62 Lester and Dussart, Colonization and the Origins of Humanitarian Governance, $142-3$.

3 See Marguerita Stephens, "Unless a Portion Be Given to the Idle": The Kulin and the New Poor Law at Port Phillip', La Trobeana: Journal of the C J La Trobe Society 16. 1 (March 2017), 41-51.

Ian Maxwell Crawford, 'William Thomas and the Port Phillip Protectorate, 18381849’ (MA Thesis, University of Melbourne, 1966), 179.

William Thomas to Charles La Trobe, 21 September 1849, VPRS 10, item 1849/1845, Public Record Office Victoria.

Arthur to Glenelg, 22 July 1837, in Cannon, The Aborigines of Port Phillip, 18351839, 2A:24-27.

${ }^{67}$ Cannon, 2A:29.

Giustiniani to Glenelg, 16 July 1838, Western Australia, Original Correspondence, CO 18/21,p. 307, National Archives of the UK.

See Lesley J. Borowitzka, 'The Reverend Dr Louis Giustiniani and Anglican Conflict in the Swan River Colony, Western Australia 1836-1838', Journal of Religious History 35. 3 (2011), 352-73.

${ }^{70}$ Louis Giustiniani, 'Letter to the Editor', Swan River Guardian, 25 May 1837, 124, http://nla.gov.au/nla.news-article214041922 (accessed 25 March 2018).

11 Ann Hunter, A Different Kind of 'Subject': Colonial Law in Aboriginal-European Relations in Nineteenth Century Western Australia, 1829-61 (North Melbourne: Australian Scholarly Publishing, 2012), 86-7.

CO 18/21, p. 168-9, National Archives of the UK.

3 Ged Martin, 'Grant, Charles, Baron Glenelg (1778-1866)', Oxford Dictionary of National Biography (Oxford: Oxford University Press, 2004), www.oxforddnb.com/view/article/7289.

74 For an account of Glenelg's downfall, see Edith Dobie, 'The Dismissal of Lord Glenelg From the Office of Colonial Secretary', Canadian Historical Review 23. 3 (1942), 280-5. 
Dobie, 'The Dismissal of Lord Glenelg', 284.

James Stephen, 12 February 1839, quoted in Dobie, 'The Dismissal of Lord Glenelg', 285.

Buxton to Sir George Grey, 23 February 1838, Papers of Sir Thomas Fowell Buxton, 1st Baronet (1), MSS Brit. Emp. S 444, vol. 17, 49-50, Bodleian Library, University of Oxford.

R. J. Cole, 'Biographical Note on John Symmons, F.R.S.', Annals of Science 10. 3 (1954), 272-3.

Will of John Symmons of Paddington House, Middlesex, PROB 11/1790/452, National Archives of the UK; Symmons' fourth marriage was reported in Dorset County Chronicle, 17 April 1828, 3.

Symmons v The Bank of England, 1832. Plaintiffs: Charles Augustus John Symmons and others. C 13/2255/26, [H1832 S4], National Archives of the UK.

1 'Mr Charles Symmons, son of Mr John Symmons', Royal Literary Fund-Case Files, British Library, Western Manuscripts, Loan 96 RLF 1/814.

Royal Institution of Great Britain, Charter and Bye Laws (London: Royal Institution of Great Britain, 1803).

83 Richard Davenport-Hines, 'Phipps, Constantine Henry, First Marquess of Normanby (1797-1863)', Oxford Dictionary of National Biography (Oxford: Oxford University Press, 2004), www.oxforddnb.com/view/article/22187.

${ }^{84}$ Western Australia, Original Correspondence, CO 18/24, p. 206, National Archives of the UK.

85 J. M. R. Cameron, 'Barrow, Sir John, First Baronet (1764-1848)', Oxford Dictionary of National Biography (Oxford: Oxford University Press, 2004), www.oxforddnb.com/view/article/1544.

36 'Barrow, Peter', British Library, India Office Records, IOR/J/1/49/138-46.

National Archives of the UK. CO 272/13-14. Blue Books, Sierra Leone, 1836-7.

William Battersby, James Fitzjames: The Mystery Man of the Franklin Expedition (Toronto: Dundurn Press, 2010), 46.

89 Colonial Times (Hobart), 29 January 1839, 7, http://nla.gov.au/nla.newsarticle8749361 (accessed 5 April 2018).

Charles O'Hara Booth, Captain Commandant, Port Arthur, to Peter Barrow, 26 December 1838, CO 18/24, p. 153, National Archives of the UK.

${ }^{1}$ Colonial Times (Hobart), 29 January 1839, 7.

Sir John Barrow to Henry Labouchere, 6 June 1839, Western Australia, Original Correspondence, CO 18/24, p. 139, National Archives of the UK.

3 Nettelbeck, "“A Halo of Protection”, 405.

Peter Barrow to Colonial Secretary, 26 April 1841, CSO Acc 36, Vol. 95, Correspondence with Protectors, folio 34-5, State Records Office of Western Australia.

95 Barrow to Colonial Secretary, 12 July, 30 September 1841, CSO Acc 36, Vol. 95, folios 50, 79.

96 Peter Barrow to the Earl of Shelburne, 3 September 1856, General Correspondence from Political and Other Departments, FO 27/1142, 1856, National Archives of the UK. See also FO 27/732, 1845.

Hutt to Lord Russell, 20 January 1842, HCPP 627, 400.

Nettelbeck, “"A Halo of Protection”, 403.

Charles Symmons, Quarterly Report, 30 June 1840, Colonial Secretary's inward correspondence, S2941, CSO Acc 36, Vol. 89, folio 59, State Records Western Australia. 
100 Charles Symmons, Quarterly Report, 30 June 1841. S2941, CSO Acc 36, Vol. 95, folio 95, State Records Western Australia.

${ }^{101}$ Charles Symmons, Annual Report for 1842, Perth Gazette and Western Australian Journal, 14 January 1843, 4, http://nla.gov.au/nla.news-article644071 (accessed 10 May 2018).

102 R. H. Bland, Annual Report for 1842, Perth Gazette and Western Australian Journal, 14 January 1843, 3, http://nla.gov.au/nla.news-article644071 (accessed 10 May 2018).

${ }^{103}$ Nettelbeck, “"A Halo of Protection”, 409.

104 'Annual Reports of the Protectors of Aborigines', The Perth Gazette and Independent Journal of Politics and News, 10 February 1849, 3.

105 Hasluck, Black Australians, 77.

${ }^{106}$ Robert Foster and Amanda Nettelbeck, Out of the Silence: The History and Memory of South Australia's Frontier Wars (Kent Town: Wakefield Press, 2012), 19.

107 Nettelbeck, “"A Halo of Protection"”; Hunter, 'Towards Amalgamationist Governance'; Ford, 'Protecting the Peace on the Edges of Empire'. 